\title{
PHYSICAL PROPERTIES OF BEECH WOOD THERMALLY MODIFIED IN HOT OIL AND IN HOT AIR AT VARIOUS TEMPERATURES
}

Bekir Cihad Bal ${ }^{1, \wedge}$

\begin{abstract}
In this study, beech wood was treated in hot oil and in hot air to determine the differences in the effects of the two processes on the physical properties of the wood. Heat treatment was conducted at temperatures of 160,190 , and $220^{\circ} \mathrm{C}$ for $2 \mathrm{~h}$ at atmospheric pressure. After the heat treatment, various properties of the wood, including mass increase in hot oil treatment (wt $\%$ gain), mass loss in hot air treatment (wt $\%$ loss), oven-dried density, swelling, equilibrium moisture content, fiber saturation point, and moisture content were determined. Regression analyses were conducted to assess the differences in mass change and volumetric swelling, and the findings were analyzed statistically. The results showed that heat treatment in hot oil influenced the physical properties of beech wood more than treatment in hot air. However, the extensive uptake of oil by the wood samples, resulting in mass increases, was a negative issue associated with the hot oil treatment.
\end{abstract}

Keywords: Anisotropy factor, equilibrium moisture content, Fagus orientalis, fiber saturation point, specific gravity, swelling.

\section{INTRODUCTION}

Heat treatment is a method that modifies the properties of wood, including its biological durability, dimensional stability, hygroscopicity, and color. Industrial production of wood that has been heat treated with hot oil and hot air increases day by day because these treatment processes are more environmentally-friendly methods than other processes that have been used in the past (Gunduz et al. 2009, Korkut 2012, Garcia et al. 2012, Cademartori et al. 2013). Different approaches are used in various thermal treatment processes, such as the Thermowood, Rectification, Plato, and Oil-heat treatment (OHT) processes. Steam, nitrogen, and oil are used as the heat transfer media in these processes (Wang and Cooper 2005). Several factors have effects on the results of heat treatment, and these factors include temperature, duration, the heat transfer medium (Esteves and Pereira 2009, Baysal et al. 2014, Schneid et al. 2014), the species of wood (hardwood or softwood) (Ibach 2010), initial moisture content (Gaff and Gasparik 2013), the density of the wood (Bal 2013a), the maturity of the wood (Bal and Bektaş 2012, Bal and Bektaş 2013, Severo et al. 2012), and the extractive content of the wood (Kortelainen et al. 2006, Bal 2013b, 2014).

The OHT process is very different from the others because it is conducted in hot oil. The temperature in the process ranges from 180 to $260^{\circ} \mathrm{C}$, and the duration is several hours. The process was patented by Sailer and Rapp 2001. When this process is used, hot oil blocks the contact between wood and oxygen. Therefore, heat treatment in hot oil has less effect on the mechanical properties than hot air (Sailer and Rapp 2001). Many researchers have studied the properties of different woods treated in different types of oil. For example, Wang and Cooper 2005, used palm oil, soy oil, and slack wax with white spruce wood, and the results showed that slack wax was better than the oils in improving the moisture content. Bazyar 2012, tested the physical properties of heat-treated aspen wood using linseed oil and reported decreased volumetric swelling, decreased equilibrium moisture content, decreased water absorption, and improved resistance to decay. Bak and Nemeth

\footnotetext{
1 Kahramanmaraş Sütçü İmam Üniversitesi, Orman Fakültesi, Orman Endüstri Mühendisliği, 46100 Kahramanmaraş. Turkey.

^ Corresponding author: bcbal@hotmail.com

Received: 23.11.2014 Accepted: 23.06.2015
} 
2012, tested heat-treated poplar wood by using sunflower, linseed, and rapeseed oils and reported increased dimensional stability and decreased moisture uptake rate. Awoyemi et al. 2009, used soy oil in their laboratory experiment as the heating medium. In another study, Tomak et al. 2011, used nut, sunflower, soybean, canola, and corn oils to determine the combined effects of boron and oil heat treatment on the properties of beech wood and Scots pine wood. Dubey et al. 2011, studied the effects of oil heating age on the physical properties of Pinus radiata wood heat treated with oil. The study produced remarkable results concerning the heat treatment of wood with oil in that the viscosity of the oil increased, and wood's ability to repel water decreased as the duration of heat treatment in the oil increased. In another study, Awoyemi et al. 2009, assessed some properties of wood that had been cooled in oil at the end of the thermal modification, and some significant results were obtained, such as decreased swelling and increased water repellency of the wood.

In previous studies, the physical properties of wood heat treated with oil were investigated from several different perspectives. However, there are limited studies that have compared the effects of heat treatment in hot oil and in hot air. Therefore, in this study, the physical properties of beech wood that had been treated in hot oil and hot air were investigated. In addition, the relationship between mass change and volumetric swelling was investigated.

\section{MATERIALS AND METHODS}

\section{Material}

Beech (Fagus orientalis L.) lumber was obtained randomly from a lumberyard in Kahramanmaraş, Turkey. The lumber was divided into two parts, i.e., heartwood and sapwood, and only the sapwood lumber was used. The sapwood lumber was cut into sticks with dimensions of $25 \times 25 \times 1000 \mathrm{~mm}$ (width $\times$ height $\mathrm{x}$ length) using a band saw machine. Then, the surfaces of the sticks were planed with a plane and processed to obtained the dimensions of $20 \times 20 \times 1000 \mathrm{~mm}$ (width $\times$ height $\times$ length). The test specimens were cut from these sticks. The dimensions of the test specimens were $20 \times 20 \times 30 \mathrm{~mm}$ (width $\mathrm{x}$ height $\mathrm{x}$ length). They were assigned to different test groups as a means of increasing the homogeneity of the wood. Twenty specimens were prepared for each test group. Eight test groups were set up, as shown in Table 1. Group 1 was the control group, and it was not subjected to any treatment. Group 5 was treated with warm oil at room conditions for $2 \mathrm{~h}$. Group 5 was used to measure the effects of the oil treatment on the physical properties of the wood samples. In the heat treatment with oil, there are three factors that influence the physical properties of the wood, i.e., the lubricating effect of the oil, the temperature of the oil, and the congestion of the cell lumens.

Table 1. Control and test groups.

\begin{tabular}{|c|c|c|c|c|}
\hline $\begin{array}{c}\text { Groups } \\
\text { Number }\end{array}$ & $\begin{array}{c}\text { Treatment } \\
\text { Media }\end{array}$ & $\begin{array}{c}\text { Treatment } \\
\text { Temperature }\left({ }^{\circ} \mathbf{C}\right)\end{array}$ & $\begin{array}{c}\text { Treatment } \\
\text { Time (h) }\end{array}$ & $\begin{array}{c}\text { Cooling } \\
\text { Media } \\
\text { (at room } \\
\text { conditions) }\end{array}$ \\
\hline $\begin{array}{c}\text { Group 1 } \\
\text { (air-control group) }\end{array}$ & - & - & - & - \\
\hline Group 2 & Hot air & 160 & 2 & air \\
\hline Group 3 & Hot air & 190 & 2 & air \\
\hline Group 4 & Hot air & 220 & 2 & air \\
\hline Group 5 & oil & 20 & 2 & oil \\
\hline (oil-control group) & Hot oil & 160 & 2 & oil \\
\hline Group 6 & Hot oil & 190 & 2 & oil \\
\hline Group 8 & Hot oil & 220 & 2 & 2 \\
\hline
\end{tabular}




\section{Methods}

After the samples were prepared, they were dried in an oven at $103 \pm 2{ }^{\circ} \mathrm{C}$ until their moisture content was $0 \%$. Then, the dimensions and weights were measured to calculate their oven-dried density. Heat treatment was performed in hot air and in hot oil at atmospheric pressure at temperatures of 160,190 , and $220^{\circ} \mathrm{C}$ for $2 \mathrm{~h}$. Hot air treatment was performed in an oven. Hot oil treatment was performed with a heater using fresh sunflower oil in the treatment. The samples were soaked in the hot oil after the target temperature was reached. After heat treatment with the oil, the samples were cooled in the oil bath for $15 \mathrm{~min}$.

After heat treatment, the weights of the samples were measured again to obtain their mass changes (mass increase in hot oil treatment and mass loss in hot air treatment). The samples were conditioned in a test cabinet at a temperature of $20 \pm 1{ }^{\circ} \mathrm{C}$ and a relative humidity of $65 \pm 5 \%$ for four weeks. Then, the weights of the samples were measured to calculate the equilibrium moisture content.

Then, the samples were immersed in water for two weeks. At the end of this period, the samples were removed from the water, and the dimensions and weights of the samples were measured to calculate their physical properties, such as swelling percentage, moisture content, and fiber saturation point. The moisture content, specific gravity, linear swelling, and volumetric swelling were determined according to Turkish standards TS 2471, TS 2472, TS 4084, and TS 4086, respectively. Mass loss (ML), mass increase (MI), and fiber saturation point (FSP) were calculated using equations (1), (2), and (3), respectively:

$$
\operatorname{ML}(\%)=\left(\left(\mathrm{M}_{1}-\mathrm{M}_{2}\right) / \mathrm{M}_{1}\right) \times 100
$$

where ML is the mass loss in the hot air treatment, $\mathrm{M}_{1}$ is the mass of the sample after being dried in an oven at $103{ }^{\circ} \mathrm{C}$ before heat treatment, and $\mathrm{M}_{2}$ is the mass of the sample after heat treatment in hot air.

$$
\operatorname{MI}(\%)=\left(\left(\mathrm{M}_{2}-\mathrm{M}_{1}\right) / \mathrm{M}_{1}\right) \times 100
$$

where $\mathrm{MI}$ is the mass increase in the hot oil treatment, $\mathrm{M}_{1}$ is the mass of the sample after being dried in an oven at $103{ }^{\circ} \mathrm{C}$ before heat treatment, and $\mathrm{M}_{2}$ is the mass of the sample after heat treatment with the oil.

$$
\operatorname{FSP}(\%)=\left(\mathrm{S}_{\mathrm{v}} / \mathrm{SG}\right)
$$

where FSP is the fiber saturation point, $\mathrm{S}_{\mathrm{v}}$ is volumetric swelling (\%), and SG is specific gravity.

\section{RESULTS AND DISCUSSION}

Test findings of physical properties after heat treatment are shown in Table 2. Group 1 was the control group, and it was not treated in high temperature air or oil. Group 5 was the oil-control group, and it was used to see the effect of high temperature, lubrication by the oil, and the congestion of lumens on the physical properties of the beech wood. The results indicated that all of the groups treated with oil were affected to a greater extent by the heat treatment than those treated with hot air. Mass change occurred as a mass loss in air treatment and as a mass increase in oil treatment. The mass losses that occurred at temperatures of 160 , 190 , and $220^{\circ} \mathrm{C}$ were 0,$6 ; 0,9$; and $4,9 \%$; respectively. It is apparent that the mass losses increased as the heat-treatment temperature increased. Similar results have been reported by other researchers in previous studies (Sailer et al. 2000, Kortelainen et al. 2006, Esteves et al. 2007, Almeida et al. 2009, Bal 2013a, Bal 2013b). But, in the oil treatment, the mass increases at heat-treatment temperatures of 160,190 and $220^{\circ} \mathrm{C}$ were 58,70 and $64 \%$, respectively, due to oil uptake. Similar results concerning mass increases during hot-oil treatment were obtained by Octavia et al. 2011. Interestingly, the mass increase at a temperature of $220^{\circ} \mathrm{C}$ was less than that at $190{ }^{\circ} \mathrm{C}$. The mass increase was lower at higher temperatures than at lower temperatures in studies conducted by Sailer et al. 2000, Sailer and Rapp 2001, and Dubey et al. 2012. Mass loss also has 
been observed during heat treatment in an oil bath, but the mass loss could not be calculated precisely (Sailer and Rapp 2001).

The equilibrium moisture content of wood is an important issue. If it can be reduced with some modification methods, the wood will be more dimensional stable and therefore more useful for some purposes. The equilibrium moisture content of the groups treated with hot oil was lower than that of the groups treated in hot air. At the temperature of $220^{\circ} \mathrm{C}$, the reduction of the equilibrium moisture content was especially remarkable, and similar results were obtained in previous studies (Bazyar 2012, Bak and Nemeth 2012). In addition, the equilibrium moisture content of hot-oil treated samples was reduced to a greater extent than that of the hot-air treated samples. It is well known that the heat treatment of wood at higher temperatures reduces the equilibrium moisture content due to the degradation of free hydroxyl $(\mathrm{OH})$ groups (Almeida et al. 2009). Concerning this issue, in a previous study, Mitsui et al. 2008; stated, "There was a clear correlation between the changes in weight of wood and the decrement of hydroxyl groups in the cellulose by thermal treatment".

Swelling values (tangential swelling, radial swelling, volumetric swelling, and swelling anisotropy) of heat-treated samples were reduced in both hot air and hot oil. Especially, at the temperature $220^{\circ} \mathrm{C}$, swelling values were extremely low. The swelling values of the test groups treated with hot oil were less than those of the test groups treated in hot air. It can be said that hot oil treatment has a greater effect on physical properties of wood than hot air treatment. In addition, the anisotropy factor $\left(\mathrm{S}_{\mathrm{t}} / \mathrm{S}_{\mathrm{r}}\right)$ also decreased. The anisotropic character of wood is one of its undesired physical properties. The swelling and shrinkage percentages of wood change in the radial, tangential and longitudinal directions. The differences of swelling and shrinkage between the directions influence the lifetime of the wood. As table 2 shows, the swelling percentages in the tangential direction were greater than those in the radial direction. At the end of heat treatment, the anisotropic factor was decreased, and it decreased more in the samples treated with hot oil. In previous studies, many researchers have noted a greater reduction of $\mathrm{S}_{\mathrm{T}}$ than that of $\mathrm{S}_{\mathrm{R}}$ (Almeida et al. 2009, Calonego et al. 2012, Dubey et al. 2012, Bal 2013b). Concerning this issue, Militz 2002 and Almeida et al. 2009 reported that the reduction in the anisotropic factor results in less tension in the wood when it is exposed to changes in climatic conditions.

The fiber saturation point of heat-treated beech wood decreased both in hot oil and hot air. The fiber saturation point of the control group was $29,4 \%$; whereas groups 4 and 8 were $171 \%$ and $7,2 \%$; respectively. Hot-oil treatment was more effective than hot-air treatment. In general, fiber saturation point of wood is $30 \%$ (Glass and Zelinka 2010). Swelling and shrinkage behavior occurs between $0 \%$ and $30 \%$ moisture content. In addition, the mechanical properties of wood changed during these intervals. Therefore, the more the fiber saturation point decreases, the more stable the mechanical properties of wood become. 
Table 2. Experimentally determined physical properties.

\begin{tabular}{|c|c|c|c|c|c|c|c|c|c|}
\hline Groups & D & MCh & EMC & $S_{t}$ & $S_{r}$ & $\mathbf{S}_{\mathrm{t}} / \mathbf{S}_{\mathrm{r}}$ & $S_{\mathrm{v}}$ & FSP & MC \\
\hline & $\mathrm{kg} / \mathrm{m}^{3}$ & $\%$ & $\%$ & $\%$ & $\%$ & - & $\%$ & $\%$ & $\%$ \\
\hline Group 1 & $\begin{array}{l}\mathbf{5 8 7} \\
(12)^{* *}\end{array}$ & - & $\begin{array}{l}\mathbf{1 1 , 1} \\
(0,4)\end{array}$ & $\begin{array}{l}\mathbf{1 1 , 6} \\
(1,1)\end{array}$ & $\begin{array}{l}\mathbf{6 , 0} \\
(0,5)\end{array}$ & $\begin{array}{l}\mathbf{1 , 9} \\
(0,2)\end{array}$ & $\begin{array}{l}\mathbf{1 7 , 6} \\
(1,3)\end{array}$ & $\begin{array}{l}\mathbf{2 9 , 4} \\
(1,5)\end{array}$ & $\begin{array}{l}67 \\
(4)\end{array}$ \\
\hline Group 2 & $\begin{array}{l}\mathbf{5 8 4} \\
(30)\end{array}$ & $\begin{array}{c}-\mathbf{- 0 , 6} \\
(0,1)\end{array}$ & $\begin{array}{l}\mathbf{1 1 , 1} \\
(0,5)\end{array}$ & $\begin{array}{l}\mathbf{1 0 , 3} \\
(1,6)\end{array}$ & $\begin{array}{l}\mathbf{5 , 8} \\
(0,5)\end{array}$ & $\begin{array}{l}\mathbf{1 , 8} \\
(0,3)\end{array}$ & $\begin{array}{l}\mathbf{1 6 , 1} \\
(1,7)\end{array}$ & $\begin{array}{l}\mathbf{2 7 , 5} \\
(2,1)\end{array}$ & $\begin{array}{l}64 \\
(4)\end{array}$ \\
\hline Group 3 & $\begin{array}{l}\mathbf{5 8 9} \\
(26)\end{array}$ & $\begin{array}{l}-\mathbf{- 0 , 9} \\
(0,2)\end{array}$ & $\begin{array}{l}\mathbf{1 0 , 2} \\
(0,2)\end{array}$ & $\begin{array}{l}\mathbf{1 0 , 2} \\
(1,0)\end{array}$ & $\begin{array}{l}\mathbf{5 , 5} \\
(0,6)\end{array}$ & $\begin{array}{l}\mathbf{1 , 9} \\
(0,2)\end{array}$ & $\begin{array}{l}\mathbf{1 5 , 8} \\
(1,3)\end{array}$ & $\begin{array}{l}\mathbf{2 6 , 8} \\
(1,5)\end{array}$ & $\begin{array}{l}\mathbf{6 0} \\
(4)\end{array}$ \\
\hline Group 4 & $\begin{array}{l}\mathbf{5 8 5} \\
(33)\end{array}$ & $\begin{array}{l}-4,9 \\
(0,9)\end{array}$ & $\begin{array}{l}\mathbf{7 , 3} \\
(0,3)\end{array}$ & $\begin{array}{l}\mathbf{6 , 3} \\
(1,2)\end{array}$ & $\begin{array}{l}\mathbf{3 , 7} \\
(0,6)\end{array}$ & $\begin{array}{l}\mathbf{1 , 7} \\
(0,2)\end{array}$ & $\begin{array}{l}\mathbf{1 0 , 0} \\
(1,8)\end{array}$ & $\begin{array}{l}\mathbf{1 7 , 1} \\
(2,4)\end{array}$ & $\begin{array}{c}\mathbf{5 3} \\
(3) \\
\end{array}$ \\
\hline Group 5 & $\begin{array}{l}\mathbf{5 8 1} \\
(35)\end{array}$ & $\begin{array}{l}\mathbf{3 1 , 5} \\
(8,5)\end{array}$ & $\begin{array}{l}\mathbf{8 , 0} \\
(0,7)\end{array}$ & $\begin{array}{l}\mathbf{1 0 , 6} \\
(1,9\end{array}$ & $\begin{array}{l}\mathbf{5 , 9} \\
(0,5)\end{array}$ & $\begin{array}{l}\mathbf{1 , 8} \\
(0,3)\end{array}$ & $\begin{array}{l}\mathbf{1 6 , 5} \\
(2,1)\end{array}$ & $\begin{array}{l}\mathbf{2 8 , 3} \\
(2,5)\end{array}$ & $\begin{array}{l}45 \\
(6)\end{array}$ \\
\hline Group 6 & $\begin{array}{l}\mathbf{5 8 2} \\
(35)\end{array}$ & $\begin{array}{l}\mathbf{5 8 , 0} \\
(12,6)\end{array}$ & $\begin{array}{l}\mathbf{5 , 4} \\
(0,7)\end{array}$ & $\begin{array}{l}\mathbf{1 0 , 3} \\
(1,7)\end{array}$ & $\begin{array}{l}\mathbf{5 , 6} \\
(0,6)\end{array}$ & $\begin{array}{l}\mathbf{1 , 9} \\
(0,3)\end{array}$ & $\begin{array}{l}\mathbf{1 5 , 9} \\
(1,8)\end{array}$ & $\begin{array}{l}\mathbf{2 7 , 2} \\
(1,8)\end{array}$ & $\begin{array}{l}27 \\
(5)\end{array}$ \\
\hline Group 7 & $\begin{array}{l}\mathbf{5 8 5} \\
(31)\end{array}$ & $\begin{array}{l}\mathbf{7 0 , 7} \\
(9,8)\end{array}$ & $\begin{array}{l}\mathbf{3 , 8} \\
(0,7)\end{array}$ & $\begin{array}{l}\mathbf{8 , 5} \\
(1,3)\end{array}$ & $\begin{array}{l}\mathbf{4 , 9} \\
(0,6)\end{array}$ & $\begin{array}{l}\mathbf{1 , 7} \\
(0,3)\end{array}$ & $\begin{array}{l}\mathbf{1 3 , 5} \\
(1,5)\end{array}$ & $\begin{array}{l}\mathbf{2 3 , 0} \\
(1,6)\end{array}$ & $\begin{array}{l}\mathbf{2 2} \\
(3)\end{array}$ \\
\hline Group 8 & $\begin{array}{l}\mathbf{5 8 1} \\
(37)\end{array}$ & $\begin{array}{l}\mathbf{6 4 , 3} \\
(10,5)\end{array}$ & $\begin{array}{l}\mathbf{3 , 2} \\
(2,3)\end{array}$ & $\begin{array}{l}\mathbf{2 , 5} \\
(0,8)\end{array}$ & $\begin{array}{l}\mathbf{1 , 7} \\
(0,4)\end{array}$ & $\begin{array}{l}\mathbf{1 , 5} \\
(0,3)\end{array}$ & $\begin{array}{l}\mathbf{4 , 2} \\
(1,2)\end{array}$ & $\begin{array}{l}7,2 \\
(17)\end{array}$ & $\begin{array}{l}\mathbf{1 5} \\
(2)\end{array}$ \\
\hline
\end{tabular}

* The mean values are shown in bold. " Standard deviations are shown in parentheses. D: oven dried density, MCh: mass change, EMC: equilibrium moisture content, St: tangential swelling, Sr: radial swelling, St/Sr: anisotropy factor, Sv: volumetric swelling, FSP: fiber saturation point, MC: moisture content at the end of immersed in water for two weeks.

After the two sets of samples were immersed in water for two weeks, the samples that were treated with hot air had higher moisture contents than the samples treated in hot oil. There are two important reasons this occurred. First, during hot-oil treatment, the oil fills the gaps in the wood. Therefore, the gaps decrease. Similar results were reported by Wang and Cooper 2005, Awoyemi et al. 2009. Second, the volumetric swelling of the samples treated with hot oil was less than that of the samples treated with hot air. As volumetric swelling decreases, the gaps in the wood samples decrease. So, the moisture content of the samples treated with hot oil was less than that in the samples treated with hot air. In addition, the lowest moisture content was measured at the temperature of $220^{\circ} \mathrm{C}$ for both hot-oil treatment (53\%) and hot-air treatment $(15 \%)$. In a previous study, similar observations were made by Dubey et al. 2012, and they noted that higher temperatures produced some chemical changes that affected dimensional stability and that the water uptake by the walls is blocked by hydrophobic oils in the lumens. In another study Tjeerdsma et al. 1998, stated that the molecular reason for the changes in the physical properties of heat-treated wood is that the cellulose microfibrils are surrounded by a firm and more inelastic network due to increased cross-linking within the lignin complex.

The main aim of the heat treatment is to alter some of the physical properties of the wood, such as equilibrium moisture content, swelling, fiber saturation point, and moisture content. So, heat-treated wood is a more dimensionally stable and less hygroscopic material for usage areas. Table 3 provides the percentage decreases in the physical properties of beech wood compared to control samples (Group 1) that were determined in this study. These findings indicated that the percentage decreases in physical properties resulting from hot-oil treatment exceeded the decreases that resulted from hot-air treatment. In addition, the findings that resulted from the tests of group 5 showed that oil treatment at room temperature significantly reduced the equilibrium moisture content (28\%) and the moisture content (33\%). 
Table 3. Percentage decreases (\%) in the properties of beech wood compared to air-control samples.

\begin{tabular}{lccccccc}
\hline Groups & EMC & St & \multicolumn{1}{c}{ Sr } & St/Sr & Sv & \multicolumn{1}{l}{ FSP } & \multicolumn{1}{l}{ MC } \\
\hline Group 2 & 0.1 & 11.0 & 3.8 & 7.5 & 8.5 & 6.3 & 3.8 \\
Group 3 & 8.2 & 11.4 & 8.3 & 3.1 & 10.3 & 8.9 & 9.9 \\
Group 4 & 34.0 & 45.7 & 37.8 & 13.3 & 43.0 & 41.9 & 20.9 \\
Group 5 & 28.1 & 8.6 & 1.5 & 7.8 & 6.2 & 3.6 & 33.2 \\
Group 6 & 51.4 & 11.2 & 7.0 & 4.0 & 9.8 & 7.5 & 59.6 \\
Group 7 & 65.5 & 26.1 & 17.8 & 9.8 & 23.2 & 21.6 & 67.8 \\
Group 8 & 71.5 & 78.2 & 71.6 & 23.7 & 76.0 & 75.5 & 76.9 \\
\hline
\end{tabular}

Percentage decreases of swelling values show also anti-swelling efficiencies (ASE). EMC: equilibrium moisture content, St: tangential swelling, Sr: radial swelling, St/Sr: anisotropy factor, Sv: volumetric swelling, FSP: fiber saturation point, MC: moisture content at the end of immersed in water for two weeks.

Table 4 gives the results of the Tukey multiple comparison tests of the treatment means for physical properties. The effects of treatment media and treatment temperature on the physical properties can be clearly seen. All of the decreases of the physical properties were significant $(p<0,001)$ except the anisotropy factor. In addition, except for $\mathrm{S}_{\mathrm{t}}$ and $\mathrm{S}_{\mathrm{v}}$, no differences were determined between control group 5 (oil-control group) and the groups treated at $160^{\circ} \mathrm{C}$.

Table 4. Tukey multiple comparison test of the treatment means for physical properties.

\begin{tabular}{|c|c|c|c|c|c|c|c|c|}
\hline & $\begin{array}{l}\text { Source of } \\
\text { Varyans }\end{array}$ & $\operatorname{EMC~(\% )~}$ & $S_{t}(\%)$ & $S_{r}(\%)$ & $\mathbf{S}_{\mathbf{t}} / \mathbf{S}_{\mathbf{r}}$ & $S_{v}(\%)$ & FSP(\%) & MC(\%) \\
\hline \multirow{2}{*}{ 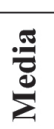 } & Air & $9,92 b^{*}$ & $9,6 \mathrm{~b}$ & $5,3 \mathrm{~b}$ & $1,8 \mathrm{a}$ & $14,9 \mathrm{~b}$ & $25,3 b$ & $61 \mathrm{~b}$ \\
\hline & Oil & $4,99 a$ & $7,9 \mathrm{a}$ & $4,5 \mathrm{a}$ & $1,7 \mathrm{a}$ & $12,5 \mathrm{a}$ & $21,1 \mathrm{a}$ & $26 a$ \\
\hline \multirow{5}{*}{ 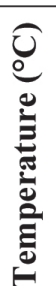 } & Group 1 & $11,09 \mathrm{~d}$ & $11,6 \mathrm{~d}$ & $6 c$ & $1,9 \mathrm{~b}$ & $17,6 \mathrm{~d}$ & $29,9 \mathrm{~d}$ & $67 \mathrm{~d}$ \\
\hline & Group 5 & $7,98 \mathrm{c}$ & $10,6 \mathrm{~cd}$ & $5,9 \mathrm{c}$ & $1,8 \mathrm{~b}$ & $16,5 \mathrm{~cd}$ & $28,3 \mathrm{c}$ & $45 \mathrm{c}$ \\
\hline & 160 & $8,24 \mathrm{c}$ & $10,3 \mathrm{bc}$ & $5,7 \mathrm{c}$ & $1,8 \mathrm{~b}$ & $15,9 \mathrm{c}$ & $27,3 \mathrm{c}$ & $46 \mathrm{c}$ \\
\hline & 190 & $7,01 \mathrm{~b}$ & $9,4 \mathrm{~b}$ & $5,2 \mathrm{~b}$ & $1,8 \mathrm{~b}$ & $14,6 \mathrm{~b}$ & $24,9 \mathrm{~b}$ & $41 \mathrm{~b}$ \\
\hline & 220 & $5,25 \mathrm{a}$ & $4,4 a$ & $2,7 \mathrm{a}$ & $1,6 \mathrm{a}$ & $7,1 \mathrm{a}$ & $12,1 \mathrm{a}$ & $34 a$ \\
\hline
\end{tabular}

${ }^{*}$ Means followed by the same letter are not significantly different.

Some previous studies have reported that there is a relationship between mass loss and the swelling properties of wood (Almeida et al. 2009, Bal and Bektaş 2012, Bal 2013b). Especially at higher temperatures, the swelling properties of wood decrease as the mass loss increases. In the present study, Figure 1-A shows the relationship between volumetric swelling and mass loss in hot-air treatment, and Figure 1-B shows volumetric swelling and mass increase in hot oil treatment, both at the temperature of $220^{\circ} \mathrm{C}$. Both relationships were negative, and both relationships were strong. The coefficients of determination $\left(\mathrm{R}^{2}\right)$ in hot-air treatment and in hot-oil treatment were determined to be 0.72 and 0.52 ; respectively. The coefficient of determination in hot-air treatment was greater than that in hot-oil treatment. The reason of this is that mass loss in the hot-air treatment occurs in the components of the cell wall, such as hemicelluloses and cellulose. But mass increase in the hot-oil treatment occurs in the cell lumens. Therefore, the relationship in the hot-air treatment is higher than that of the hot-oil treatment. 

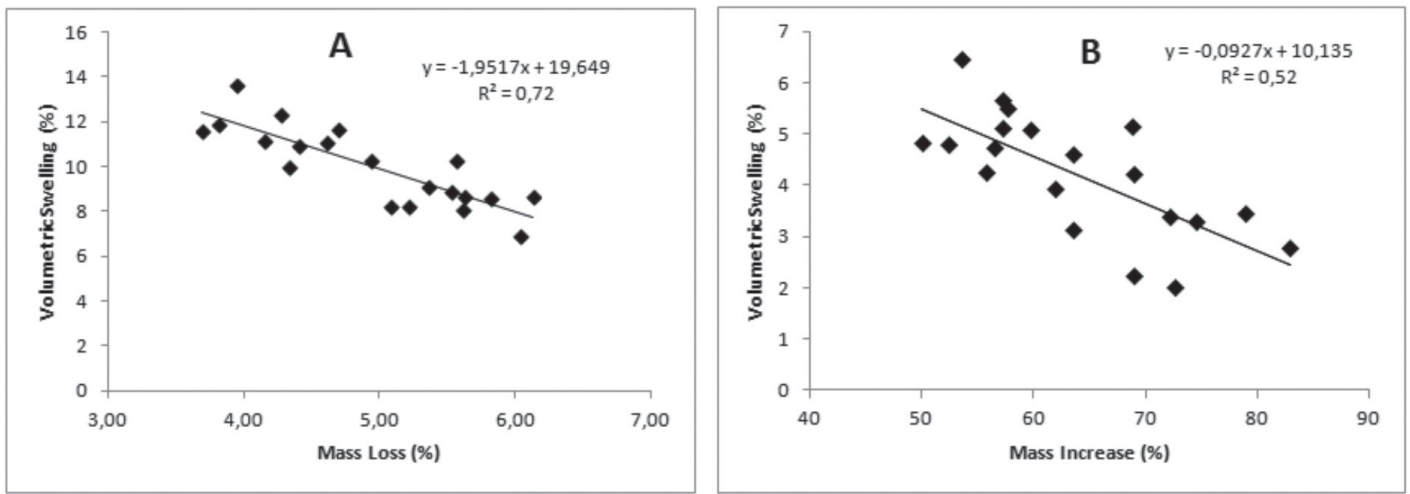

Figure 1. (A) Relationship between volumetric swelling and mass loss for hot-air treatment at $220^{\circ} \mathrm{C}$; (B) relationship between volumetric swelling and mass increase for hot-oil treatment at $220^{\circ} \mathrm{C}$

\section{CONCLUSIONS}

In this study, some physical properties of beech wood heat-treated in hot oil and in hot air were investigated, i.e., mass change, swelling percentage, anisotropic factor, equilibrium moisture content, fiber saturation point, and moisture content. According to the findings, the following results can be stated:

According to Tukey multiple comparison tests, the physical properties of beech wood treated in hot oil and in hot air at temperatures of 190 and $220^{\circ} \mathrm{C}$ were significantly different from those of the control samples.

Dimensional stability, equilibrium moisture content, fiber saturation point, and the moisture content of the samples treated with hot oil decreased to a greater extent than those for the samples treated with hot air.

Generally, it can be said that the heat treatment medium used has a significant effect on the results of the heat-treatment process. At the same temperatures for hot oil and hot air, the hot oil was more effective as a heat-carrying material and for inhibiting the contact of oxygen with the wood samples.

Treatment of the samples with oil at room temperature for $2 \mathrm{hr}$ decreased their equilibrium moisture content and moisture content.

Regression analyses provided the relationships between mass change and volumetric swelling percentages for the samples treated with hot oil and the samples treated with hot air. 


\section{REFERENCES}

Almeida, G.; Brito, J.O.; Perre, P. 2009. Changes in wood-water relationship due to heat treatment assessed on micro-samples of three Eucalyptus species. Holzforschung 63(1):80-88.

Awoyemi, L.; Cooper, P.A.; Ung, T.Y. 2009. In-treatment cooling during thermal modification of wood in soy oil medium: soy oil uptake, wettability, water uptake and swelling properties. European Journal of Wood and Wood Products 67(4):465-470.

Bazyar, B. 2012. Decay resistance and physical properties of oil heat treated aspen wood. Bioresources 7(1):696-705.

Bak, M.; Nemeth, R. 2012. Changes in swelling properties and moisture uptake rate of oil-heat-treated poplar (Populous x euramericana cv. Pannonia) wood. Bioresources 7(4):5128-5137.

Bal, B.C.; Bektaş, I. 2012. The effects of heat treatment on the physical properties of juvenile wood and mature wood of E. grandis. Bioresources 7(4):5117-5127.

Bal, B.C.; Bektaş, I. 2013. The effects of heat treatment on some mechanical properties of juvenile wood and mature wood of Eucalyptus grandis. Drying Technology 31(4): 479-485.

Bal, B.C. 2013a. A comparative study of the physical properties of thermally treated poplar wood and plane wood. Bioresources 8(4):6493-6500.

Bal, B.C. 2013b. Effects of heat treatment on the physical properties of heartwood and sapwood of Cedrus Libani. Bioresources 8(1): 211-219.

Bal, B.C. 2014. Some physical and mechanical properties of thermally modified juvenile and mature black pine wood. European Journal of Wood and Wood Products 72(1):61-66.

Baysal, E.; Kart, S.; Toker, H.; Degirmentepe, S. 2014. Some physical characteristics of thermally modified oriental-beech wood. Maderas. Ciencia y tecnología 16(3): 291-298.

Cademartori, P.H.G.; Santos, P.S.B.; Serrano, L.; Labidi. J.; Gatto, D.A. 2013. Effect of thermal treatment on physicochemical properties of Gympie messmate wood. Industrial Crops and Products 45: 360-366.

Calonego, F.W.; Severo, E.T.D.; Ballarin, A.W. 2012. Physical and mechanical properties of thermally modified wood from E. grandis. European Journal of Wood and Wood Products 70(4): 453-460.

Esteves, B.; Domingos, I.; Pereira, H. 2007. Improvement of technological quality of eucalypt wood by heat treatment in air at $170-200^{\circ}$ C. Forest Products Journal 7(1-2): 47-52.

Esteves, B.M.; Pereira, H.M. 2009. Wood modification by heat treatment: A review. Bioresources 4(1): 370-404.

Dubey, M.K.; Pang, S.; Walker, J. 2011. Effect of oil heating age on color and dimensional stability of heat treated Pinus radiata. European Journal of Wood and Wood Products 69(2): 255-262.

Dubey, M.K.; Pang, S.; Walker, J. 2012. Changes in chemistry, color, dimensional stability and fungal resistance of Pinus radiata D. Don wood with oil heat-treatment. Holzforschung 66(1): 49-57. 
Gaff, M.; Gašparík, M. 2013. Shrinkage and stability of thermo-mechanically modified aspen wood. BioResources 8(1): 1136-1146.

Garcia, R.A.; Carvalho, A. M.; Latorraca, J.V.F.; Matos, J.L.M. Santos, W.A.; Silva, R.F.M. 2012. Nondestructive evaluation of heat-treated Eucalyptus grandis Hill ex Maiden wood using stress wave method. Wood Science and Technology 46(1-3): 41-52.

Glass, S.V.; Zelinka, S.L. 2010. Moisture Relations and Physical Properties of Wood, Wood Handbook: Wood as an engineering Material, USDA Forest Service, Forest Products Laboratory, General Technical Report FPL-GTR-190, Madison, WI, p. 4-2.

Gunduz, G.; Korkut, S.; Aydemir, D.; Bekar, I. 2009. The density, compression strength and surface hardness of heat treated hornbeam (Carpinus betulus L.) wood. Maderas. Ciencia y tecnología 11(1): 61-70.

Ibach, R.E. 2010. Specialty treatments, Wood Handbook: Wood as an engineering Material, USDA Forest Service, Forest Products Laboratory, General Technical Report FPL-GTR-190, Madison, WI, p. 19-9.

Korkut, S. 2012. Performance of three thermally treated tropical wood species commonly used in Turkey. Industrial Crops and Products 36 (1):355-362.

Kortelainen, S.M.; Antikainen, T.; Viitaniemi, P. 2006. The water absorption of sapwood and heartwood of Scots pine and Norway spruce heat-treated at $170{ }^{\circ} \mathrm{C}, 190{ }^{\circ} \mathrm{C}, 210{ }^{\circ} \mathrm{C}$ and $230{ }^{\circ} \mathrm{C}$. Holz als Roh-und Werstoff 64 (3):192-197.

Militz, H. 2002. Heat treatment technologies in Europe: Scientific background and technological stateof-art, in: Proceedings of Conference on "Enhancing the durability of lumber and engineered wood products" February 11-13, 2002, Kissimmee, Orlando. Forest Products Society, Madison, US.

Mitsui, K.; Inagaki, T.; Tsuchikawa, S. 2008. Monitoring of hydroxyl groups in wood during heat treatment using NIR spectroscopy. Biomacromolecules 9 (1): 286-288.

Octavia, Z.; Anne-Maria, B.L.; Beldean, E. 2011. Improvements in Stability of the Oil Treated Wood, Recent Researches in Energy, Environment and Landscape Architecture, Proceedings of the $4^{\text {th }}$ IASME/ WSEAS International Conference on Landscape Architecture, Angers, France, November 17-19.

Sailer, M.; Rapp, A.O.; Leithoff, H.; Peek, R.D. 2000. Upgrading of wood by application of an oil heat treatment. Holz Roh- und Werkst 58(1):15-22.

Sailer, M.; Rapp, O.A. 2001. Wood treatment process, United States Patent, Patent No: US 6217939B1.

Schneid, E.; Gonzalez, de Cademartori, P. H.; Gatto, D. 2014. The effect of thermal treatment on physical and mechanical properties of Luehea divaricata hardwood. Maderas. Ciencia y tecnología 16(4): 413-422.

Severo, E.T.D.; Calonego, F.W.; Sansigolo, C.A. 2012. Physical and chemical changes in juvenile and mature woods of Pinus elliottii var. Elliottii by thermal modification. European Journal of Wood and Wood Products 70: 741-747.

Tomak, E.D.; Viitanen, H.; Yildiz, U.C.; Hughes, M. 2011. The combined effects of boron and oil heat treatment on the properties of beech and Scots pine wood. Part 2: Water absorption, compression strength, color changes, and decay resistance. Journal of Materials Science 46: 608-615. 
Tjeerdsma, B.F.; Boonstra, M.; Pizzi, A.; Tekely, P.; Militz, H. 1998. Characterization of thermally modified wood: molecular reasons for wood performance improvement. Holz als Roh-und Werkstoff 56(3): 149-153.

TS 2471 1976. Wood-determination of moisture content for physical and mechanical tests, Turkish Standard Institution, Turkey.

TS 2472 1976. Wood-determination of density for physical and mechanical tests, Turkish Standard Institution, Turkey.

TS 4084 1984. Wood-determination of radial and tangential swelling, Turkish Standard Institution, Ankara, Turkey.

TS 4086 1983. Wood-determination of volumetric swelling, Turkish Standard Institution, Turkey.

Wang, J.Y.; Cooper, P.A. 2005. Effect of oil type, temperature and time on moisture properties of hot oil-treated wood. Holz als Roh-und Werkstoff 63: 417-422. 